\title{
Preface: The Power of Trust
}

The ruble lived, the ruble lives, the ruble will continue to live.

-Russian Finance Minister Boris Fedorov, 1992

17 hat do democratic politics and banking have in common? While the cynics among us may guess venality, or the pursuit of power, the underlying answer is that both rely on trust to survive. A democratic political system is undermined if its citizens do not trust it to represent their political and economic interests. Likewise, if a bank loses the trust of its clients, they will withdraw their money and the bank will collapse. Money itself is an ephemeral, trust-based phenomenon, existing as a means of payment and a store of value only as long as people widely believe it to be capable of doing so.

In the 199os, Russia faced the challenge of building public trust in its young democracy and in its newly liberalized banking system-tasks made doubly difficult by Soviet-era legacies of political prevarication and command economics. By 1998, Russia had failed at both of these tasks. An article in the newspaper Komsolmol'skaia pravda neatly summed up the state of the emerging Russian banking system. It told the story of an elderly pensioner who lost her entire life savings of one million rubles because she had stored the money in her basement, where it was eaten by rats. The paper observed that "the lady, having studied a variety of Russian state and commercial banks, concluded that her cash was safest in the cellar."

1. "Rats Devour Villager's Savings," Associated Press, November 2, 1994. At November 1994 exchange rates, she had about $\$ 300$. 
Instead of developing a stable, law-based political and economic system, post-Soviet Russia became known as the "Wild East," a country where order had been replaced by a society "without limits" (bezpredel). Murder, financial scams, casinos, and cronyism characterized Russian life, especially in the capital city of Moscow. Russia's bankers, now grown wealthy and influential, occupied the center of this seedily compelling world. Indeed, the influence of the Russian banking system on the emergence of market democracy during this period of transformation was overwhelmingly negative. Its politically autonomous yet technically underdeveloped central bank carried out monetary policy in a secretive, uncoordinated, destabilizing manner. Worse, its commercial bankers played an increasingly important role in the political system, with the most powerful banks acquiring state property cheaply and forming a so-called financial-industrial oligarchy. The bankers and the state both came to depend upon each other for survival, while most Russian enterprises withdrew further and further from the cash-based economy. In 1998, after undergoing ten years of economic "reforms," the Russian financial system collapsed.

This book explores these pathological developments by tracing the causes, processes, and ultimate effects of institutional change in Russia's banking system from the initial decision to break up the Soviet central bank in 1987 through the aftermath of the August 1998 banking crash. It argues that in Russia, a disastrous combination of perverse, Soviet-era institutional legacies and misguided, Western-inspired policy choices led to the creation of a banking system so parasitic that it ultimately undermined Russia's economic transformation. In particular, the liberalization of the Soviet financial system while the rest of the command economic structure remained intact led to an "irony of autonomy." Even though this liberalization granted banks more freedom from central government control, autonomy did not contribute to the development of competitive, market-oriented, or efficient institutions. On the contrary, it spawned banks that served to enrich the few while failing to help build a market economy in Russia. Even after they became independent, Russia's commercial banks continued to turn to the state for sustenance. At the same time, the Russian government became dependent on the political and financial support of the most prominent bankers in order to maintain its control over the country.

In researching this book, I spent eight months in three fascinating Russian cities between 1994 and 1997. These included Moscow, Russia's capital and largest city; Riazan', a depressed, mid-sized industrial town about 200 kilometers southeast of Moscow; and Volgograd (formerly Stalingrad), a large industrial and agricultural city on the Volga River in southern Russia. Since the early Soviet era, Moscow has been the country's unquestioned political and financial center. As of January 1998, over one-third of all Russian banks were headquartered in Moscow, including 
19 of the 20 largest. Riazan' and Volgograd, on the other hand, represent relatively average regions demographically, economically, and politically. Neither city was a major exporter of a single commodity (like Tiumen', an oil-producing region of Siberia), nor a semi-autonomous economic region that operated as a tax haven (like Dagestan or Bashkortostan). Nor did these regions enjoy a special political status (like Tatarstan). Volgograd had a slightly larger-than-average financial market, while Riazan's was slightly smaller.

My research in these cities involved interviewing numerous Russian bankers, policymakers, entrepreneurs, and academics; reading archival issues of local newspapers and journals; participating in banking conferences in Moscow and St. Petersburg; and analyzing primary source materials on Russian and Soviet banking from the Association of Russian Banks, the Financial Services Volunteer Corps, Dialog Bank, Inkombank, the Interbank Financial House, the Central and East European Legal Initiative, the Barents Group, the Riazan' Pedagogical University, the Central Bank of Russia, Volgograd State University, the Russian State Duma, and the Russian Federation Council, among others.

In this book, I have used the most reliable statistics available from both Western and Russian sources. However, the quality of financial statistics in the 1980 and 199 os leaves much to be desired. The Central Bank of Russia has changed its methodology over time. Little consistency exists between one information source and another. Russian accounting standards, on which many of these statistics are based, inflate bank assets in comparison with international accounting standards. Moreover, banks have had every incentive to cook their books throughout the transformation period. As a result, exact figures should be treated with caution. Even a statistic as seemingly straightforward as the number of banks in a region may be slightly off, depending on whether or not defunct banks have been included. In many instances the relative relationship among statistics, rather than the discrete figures themselves, reveals the more important and valid findings.

In crafting this book I have inevitably amassed financial, professional, and personal debts as large and unrepayable as those of the Russian banking system. For supporting my research and writing, I thank the Social Science Research Council, the American Council of Teachers of Russian, the Center of International Studies at Princeton University, the Council on Regional Studies at Princeton, the Brookings Institution, and Loyola University Chicago. I also appreciate receiving permission to reprint material from two earlier essays: "Misguided Autonomy: Central Bank Independence and the Russian Transition," which appeared in Andreas Schedler, Larry Diamond, and Marc Plattner, eds., The Self-Restraining State: Power and Accountability in New Democracies (Lynne Rienner, 1999); and "Russia's 
Emerging Financial-Industrial Groups," Post-Soviet Affairs, vol. 13, no. 4, pp. 333-365 (○V.H. Winston \& Son, Inc., 36o South Ocean Boulevard, Palm Beach, Fla. $334^{80}$. All rights reserved). Chapter three is a substantially revised and updated version of the former, while revised sections from the latter appear in chapters five and six.

I owe endless gratitude to those Russians in Moscow, Riazan', and Volgograd who revealed the secrets of their marvelous, maddening country to me. In Riazan', I particularly thank the Central Bank's indefatigable regional director Tamara Pigilova, Sergei Kostikov of the Riazan' Pedagogical University, and Oleg Churbanov and the entire staff of PRIO-Vneshtorgbank. In Volgograd, Evgenii Komarnitskii of RIT Bank and Daniil Zakharov of Russkaia Nedvizhimost' went out of their way to explain the intricacies of Russian regional banking to me. In particular, though, I thank Nadezhda Filipovna, who gave me unique insights into Russia's past and present and taught me to make authentic blini. In Moscow, thanks go out especially to Peter Derby at Dialog Bank, Aleksandr Zagriadskii at the Association of Russian Banks, Liuba Ternova at the Federation Council, Garegin Tosunian at Tekhnobank, the Interbank Financial House, and Duma member Pavel Medvedev. In addition, while in Russia I benefited enormously from discussions with Michael McFaul and Michael Davey, and from the friendship of Karen Bradbury, Laura Kennedy, and Chris Boffey.

When asked about how best to design the Russian financial system, the central bank's once and future director Viktor Gerashchenko observed that "We hardly need to take the United States as a model. It is a country with its own painfully specific features. We must not forget that it is 200 years old and has been settled mainly by rebels, adventurists, and misfits, by what one may call dissidents who did not get on in their native civilizations and were drawn to the undeveloped continent, where they could do, think up, and try whatever they liked." Stephen Cohen and Nancy Bermeo happily allowed me to do, think up, and try whatever I liked (within reason), and supported me throughout my work. Kathleen Thelen's theoretical insights on institutionalism inspired my own. Larry Diamond sparked my interest in democratization, encouraged me to pursue graduate study in political science, and persuaded me through his example that an academic life could actually be exciting. Andrew Barnes and I went through graduate school, fieldwork, and writing together; I cannot imagine having a better colleague or friend. Joel Hellman graciously answered my early, naive questions about Russian banking when

2. Quoted in Vitalii Kovalenko, "Viktor Gerashchenko: Reform Is Not a Horse, It Will Not Save Us Itself," Rossiiskaia gazeta, April 24, 1993, 5, trans. FBIS-SOV, April 28, 1993 , $35-36$. 
he did not need to do so. My colleagues at Princeton, Brookings, and Loyola were interested and supportive throughout this process. Roger Haydon of Cornell University Press first snapped up the manuscript and then tore it apart, both of which I thoroughly appreciated. Clancy Broxton worked over the multi-fonted endnotes and bibliography, while Daniel Karnes expertly designed the maps in chapter five. My family, especially my mother Margaret and my brother Erik, provided the foundation upon which I have built my work and my life. This book is dedicated to the memory of my father, Roger Johnson, who loved the Wild West.

Most importantly, though, I want to thank my husband Ben Forest. He made finishing this book much more pleasant than I could ever have imagined, and I believe he hopes I never write another one.

Budapest, Hungary

JULIET JOHNSON 
